\title{
Step Relative
}

National Cancer Institute

\section{Source}

National Cancer Institute. Step Relative. NCI Thesaurus. Code C71395.

A family relation established through a subsequent marriage of your parent. 